\title{
Faktor Risiko Sindrom Premenstruasi pada Sampel Urban di Jakarta Februari-Maret 2018
}

\author{
Keisha D. Christie ${ }^{1}$, Theresia Citraningtyas ${ }^{2}$, Elly Ingkiriwang ${ }^{2}$, A. Aries \\ Soesanto ${ }^{3}$
}

\author{
${ }^{1}$ Mahasiswa Fakultas Kedokteran Universitas Kristen Krida Wacana \\ ${ }^{2}$ Staf Pengajar Bagian IKJ Fakultas Kedokteran Universitas Kristen Krida Wacana \\ ${ }^{3}$ Staf Pengajar Bagian IKM Fakultas Kedokteran Universitas Kristen Krida Wacana \\ Alamat Korespondensi: keisha.2014fk078@civitas.ukrida.ac.id
}

\begin{abstract}
Abstrak
Sindrom premenstruasi (PMS) merupakan kumpulan gejala yang dapat menganggu produktivitas dan kualitas hidup. Untuk memahami sindrom premenstruasi yang terjadi di kelompok masyarakat perkotaan, dilakukan penelitian terhadap beberapa faktor risiko. Penelitian ini dilakukan untuk mengidentifikasi hubungan faktor risiko (usia saat ini, usia menarche, status perkawinan, jumlah anak, pendidikan, status sosioekonomi dan pekerjaan, riwayat keluarga) terhadap sindrom premenstruasi. Pengambilan sampel dilakukan secara purposive cross-sectional pada kelompok perempuan usia subur di Nafiri Discipleship Church Central Park untuk mewakilkan populasi urban. Data yang dikumpulkan dianalisa dengan uji korelasi bivariat Spearman. Didapatkan sebanyak 75 subjek penelitian. Karakteristik subjek mayoritas berusia 22-29 tahun, belum kawin, mengalami menstruasi pertama pada usia 13-15 tahun, memiliki gelar D3/S1, dan memiliki riwayat keluarga dengan sindrom premenstruasi. Hasil skrining dengan Premenstrual Symptoms Screening Tool (PSST) menunjukkan 58,7\% responden mengalami sindrom premenstruasi ringan atau tidak bergejala, diikuti dengan $37,3 \%$ responden sugestif PMS sedang sampai berat. Ditemukan hubungan signifikan antara hasil skrining dengan variabel usia menarche $(p=0,005)$ dan riwayat keluarga $(\mathrm{p}=0,004)$. Penelitian ini menggambarkan masalah yang dapat mengganggu produktivitas dan kualitas hidup perempuan daerah perkotaan. Satu dari tiga perempuan pada sampel ini mengalami PMS sedang sampai berat. Perlu dilakukan penelitian lanjutan untuk menelusuri peran faktor risiko terhadap timbulnya PMS.
\end{abstract}

Kata kunci: kesehatan perkotaan, kesehatan reproduksi, sindrom premenstruasi

\section{Risk Factors for Premenstrual Syndrome in Women in an Urban Sample in Jakarta, February-March 2018}

\begin{abstract}
Premenstrual syndrome (PMS) is a collection of symptoms that could disturb productivity and quality of life. To improve understanding of PMS in urban population, potential risk factors were assessed. The research aimed to identify the correlation of risk factors (age, age of menarche, marital status, parity, education, socioeconomic and employment, family history) with PMS. The research used cross-sectional purposive sampling among women of reproductive age at Nafiri Discipleship Church Central Park to represent an urban population. The data was analyzed using Spearman bivariate correlation test. A total of75 women participated. The majority was 22-29 years, single, reported their first menstruation at 13-15 years of age, had obtained a bachelor's degree/university diploma, and reported a family history of PMS. Screening results using Premenstrual Symptoms Screening Tool
\end{abstract}


(PSST) showed that $58.7 \%$ of respondents were asymptomatic or had mild PMS, with $37.3 \%$ respondents were suggestive moderate to severe PMS. Significant correlation obtained between screening results with age of menarche $(p=0.005)$ and family history $(p=0.004)$. This portrays a problem that potentially hinders productivity and quality of life in urban women. One of third sample suffered from medium to severe PMS. Further studies need to be conducted among other urban populations to look further into the role of risk factors in PMS.

Keywords: premenstrual syndrome, urban women, reproductive health

\section{Pendahuluan}

Sindrom premenstruasi atau premenstrual syndrome (PMS) merupakan kumpulan gejala fisik maupun emosional yang terjadi beberapa hari sebelum menstruasi. ${ }^{1}$ PMS terjadi dalam fase luteal dalam siklus menstruasi. ${ }^{2}$ Sekitar $80 \%$ perempuan diduga menderita $\mathrm{PMS}^{3}{ }^{3} \mathrm{Di}$ masyarakat luas, masih ditemukan perspektif yang menyatakan bahwa PMS bukan penyakit, dan hanya merupakan kejadian normal pada perempuan. ${ }^{2}$ Padahal, PMS dapat mengganggu efisiensi dan produktivitas kerja, serta menimbulkan kendala dalam hubungan dengan keluarga, teman, atau rekan kerja, maupun dalam kehidupan sosial serta tanggung jawab lainnya. ${ }^{4}$

Penyebab terjadinya PMS hingga saat ini belum diketahui dengan jelas. ${ }^{1}$ Beberapa teori yang masih digunakan hingga saat ini erat kaitannya dengan hormon seks dan steroid pada perempuan. ${ }^{1}$ Menurut teori tersebut, sebagian perempuan lebih sensitif terhadap hormon progesteron dan estrogen. ${ }^{1}$ Selain itu, ada juga teori bahwa perempuan yang mengalami PMS memiliki kadar serotonin yang lebih rendah. ${ }^{1}$

Penelitian sebelumnya menunjukkan siklus menstruasi dipengaruhi oleh faktor lingkungan. ${ }^{5}$ PMS juga dapat berdampak pada fungsi sosial dan pekerjaan. ${ }^{6}$ Perempuan urban (perkotaan) merupakan kelompok khusus yang perlu diteliti. ${ }^{7}$ Penelitian ini dilaksanakan dengan tujuan untuk mengetahui faktor-faktor yang berhubungan dengan PMS pada kelompok perempuan perkotaan. Selain itu, penelitian ini dapat bermanfaat untuk memperluas wawasan dan pengetahuan masyarakat mengenai PMS dan dapat meningkatkan kesadaran subjek penelitian terhadap gejala PMS yang dideritanya.

\section{Metode Penelitian}

Dalam penelitian ini, populasi yang digunakan adalah perempuan yang beribadah di Nafiri Discipleship Church Central Park, Jakarta Barat. Subjek penelitian diambil dengan cara purposive sampling, yaitu memilih subjek sesuai dengan karakteristik dan tujuan penelitian. Karakteristik subjek yang mengalami sindrom premenstruasi adalah perempuan dalam usia produktif. Peneliti membagikan kuisioner pada subjek yang memenuhi kriteria dan bersedia untuk menjadi responden. Subjek juga telah menerima informed consent dan penjelasan sebelumnya.

Instrumen yang digunakan adalah Premenstrual Symptoms Screening Tool (PSST) sesuai rekomendasi Royal College of Obstetrics and Gynaecologists. ${ }^{1}$ dan kuisioner data diri yang mencakup status perkawinan, jumlah anak, usia menarche, pendidikan, pekerjaan, pendapatan per bulan, pengeluaran pribadi, pengeluaran keluarga, dan riwayat keluarga. PSST sudah banyak digunakan di Indonesia dengan banyak versi adaptasi. ${ }^{4}$ Penelitian ini menggunakan PSST asli dengan tambahan penjelasan/keterangan, sesuai dengan kondisi bahwa populasi tersebut merupakan kelompok urban Jakarta yang berkegiatan rutin dalam Bahasa Inggris.

Pengambilan data dilakukan satu kali, dengan pendekatan cross-sectional. Data yang diambil disortir kedalam tolok ukur yang sudah ditentukan dan disajikan dalam tabel, serta dianalisis dengan uji korelasi bivariat Spearman untuk variabel nominalordinal dan numerik-ordinal.

Sampel penelitian merupakan perempuan usia 18-35 tahun di Nafiri Discipleship Church Central Park Jakarta Barat yang datang beribadah pada bulan Februari-Maret 2018. Sampel harus memenuhi kriteria inklusi dan kriteria eksklusi, diantaranya perempuan yang tidak 
menggunakan kontrasepsi hormonal, tidak sedang hamil, tidak merokok, dan tidak menderita ketergantungan alkohol.

Menurut World Health Organization (WHO), perempuan usia subur adalah perempuan dalam rentang usia 15-49 tahun. ${ }^{8}$ Batas bawah usia sampel pada penelitian ini adalah usia 18 tahun berdasarkan patokan umur yang dianggap kompeten untuk mengambil keputusan untuk menjadi responden. ${ }^{9}$ Selain itu, dibutuhkan waktu 1-2 tahun setelah menarche untuk terjadinya maturitas kelenjar seks dan steroid yang dapat mengatur siklus menstruasi menjadi reguler. $^{10}$

Batas atas usia sampel adalah 35 tahun, dengan pertimbangan bahwa pada usia 35 tahun ke atas gejala premenstruasi didapatkan lebih ringan dibandingkan usia lebih muda, serta untuk menyingkirkan peningkatan risiko terjadinya mioma uteri seiring meningkatnya usia. ${ }^{11}$ Peneliti menggunakan klasifikasi International Society for Premenstrual Disorders (ISPMD) yang membagi Premenstrual Disorders (PMD) menjadi tipikal dan atipikal. ${ }^{12}$ Dalam penelitian ini, cakupan peneliti hanya di ranah PMD tipikal, dengan PMS yang ada dominan gejala fisik atau PMS dengan dominan gejala emosional (Premenstrual Dysphoric Disorder-PMDD). ${ }^{12}$ Sehingga, PMD atipikal yang disebabkan karena penyakit lain yang memperberat gejala premenstruasi berada di luar cakupan penelitian.

\section{Kaji Etik}

Penelitian ini telah mendapatkan keterangan lolos kaji etik dari Komite Etik Penelitian Medis \& Kesehatan Fakultas Kedokteran Universitas Kristen Krida Wacana, Jakarta Barat dengan nomor pengajuan 522/SLKEIM/UKKW/FK/KE/ II/2018.

\section{Analisis Statistik}

Penelitian ini menggunakan uji hipotesis non-parametrik, yaitu korelasi bivariat Spearman dengan menggunakan software IBM SPSS versi 24.

\section{Hasil Penelitian}

Jumlah total subjek yang mengisi instrumen penelitian sebanyak 78 orang. Tiga sampel dikeluarkan karena data yang tidak lengkap (tidak mengisi data diri). Variabel bebas yang diukur pada subjek dalam penelitian ini adalah: usia saat ini, status perkawinan, jumlah anak, usia menarche, pendidikan, pekerjaan, pendapatan per bulan, pengeluaran pribadi, pengeluaran keluarga, dan riwayat keluarga. Hasil yang diperoleh untuk masing-masing variabel bebas terdapat pada Tabel 1 .

Berdasarkan PSST, lebih dari sepertiga responden melaporkan kondisi yang sugestif PMS sedang sampai berat. Bahkan 4\% melaporkan kondisi yang sugestif PMDD. Diagram hasil skrining berdasarkan PSST dapat dilihat pada Gambar 1 .

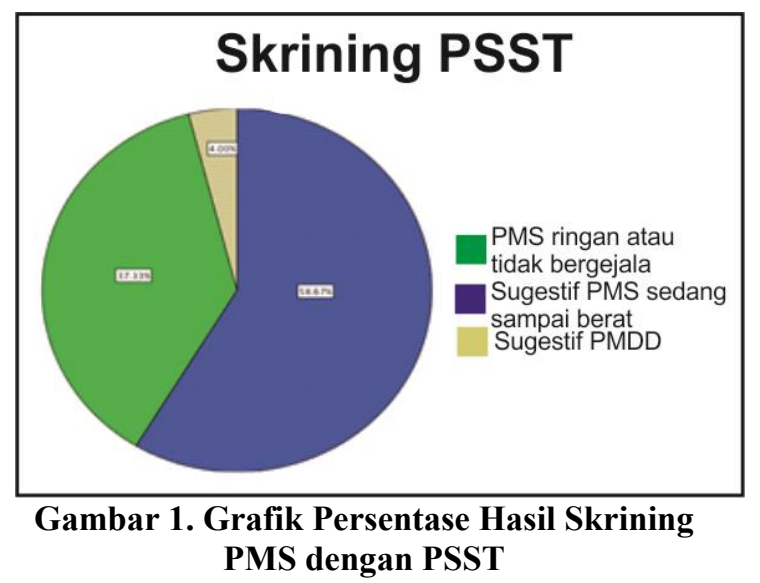

Tabel 2. Analisis Korelasi Bivariat Variabel Penelitian dengan PMS

\begin{tabular}{|c|c|c|}
\hline Hubungan Variabel & $\begin{array}{c}\mathrm{p} \\
\text { value }\end{array}$ & $\begin{array}{c}\text { Koefisien } \\
\text { korelasi }\end{array}$ \\
\hline Usia saat ini-PMS & 0,684 & 0,048 \\
\hline Usia menarche- & & \\
\hline PMS & 0,005 & (-) 0,321 \\
\hline Status perkawinan- & & \\
\hline PMS & 0,205 & (-) 0,148 \\
\hline Jumlah anak-PMS & 0,300 & (-) 0,121 \\
\hline Pendidikan-PMS & 0,172 & (-) 0,159 \\
\hline Pekerjaan-PMS & 0,253 & 0,134 \\
\hline Pendapatan/bulan- & & \\
\hline PMS & 0,479 & (-) 0,083 \\
\hline $\begin{array}{l}\text { Pengeluaran } \\
\text { pribadi-PMS }\end{array}$ & 0,655 & (-) 0,052 \\
\hline Pengeluaran & & \\
\hline keluarga-PMS & 0,187 & (-) 0,154 \\
\hline Riwayat keluarga- & & \\
\hline PMS & 0,004 & 0,332 \\
\hline
\end{tabular}


Tabel 1. Karakteristik Subjek Penelitian

\begin{tabular}{|c|c|c|c|}
\hline Faktor risiko & Tolok ukur & Frekuensi & $\begin{array}{c}\text { Proporsi } \\
(\%)\end{array}$ \\
\hline \multirow{5}{*}{$\begin{array}{l}\text { Interval usia saat ini } \\
\text { (tahun) }\end{array}$} & $18-21$ & 14 & 18,7 \\
\hline & $22-25$ & 25 & 33,3 \\
\hline & $26-29$ & 26 & 34,7 \\
\hline & $30-33$ & 4 & 5,3 \\
\hline & $>33$ & 6 & 8 \\
\hline \multirow[t]{3}{*}{ Status perkawinan } & Belum kawin & 66 & 88 \\
\hline & Sudah kawin & 9 & 12 \\
\hline & Janda & 0 & 0 \\
\hline \multirow[t]{3}{*}{ Jumlah anak (orang) } & 0 & 70 & 93,3 \\
\hline & 1 & 3 & 4 \\
\hline & 2 & 2 & 2,7 \\
\hline \multirow{4}{*}{$\begin{array}{c}\text { Interval usia } \\
\text { menarche (tahun) }\end{array}$} & $<10$ & 3 & 4 \\
\hline & 10-Des & 30 & 40 \\
\hline & $13-15$ & 38 & 50,7 \\
\hline & $>15$ & 4 & 5,3 \\
\hline \multirow[t]{4}{*}{ Pendidikan } & $\mathrm{SD} / \mathrm{SMP}$ & 0 & 0 \\
\hline & SMA/SMK & 28 & 37,3 \\
\hline & $\mathrm{D} 3 / \mathrm{S} 1$ & 46 & 61,3 \\
\hline & S2 & 1 & 1,3 \\
\hline \multirow[t]{2}{*}{ Pekerjaan } & Tidak bekerja & 14 & 18,7 \\
\hline & Bekerja & 61 & 81,3 \\
\hline \multirow{5}{*}{$\begin{array}{l}\text { Interval Pendapatan } \\
\text { per bulan (juta } \\
\text { rupiah) }\end{array}$} & $<3$ & 10 & 13,3 \\
\hline & 03-Jun & 39 & 52 \\
\hline & 06-Sep & 16 & 21,3 \\
\hline & 09-Des & 7 & 9,3 \\
\hline & $>12$ & 3 & 4 \\
\hline \multirow{5}{*}{$\begin{array}{l}\text { Interval Pengeluaran } \\
\text { Pribadi per bulan } \\
\text { (juta rupiah) }\end{array}$} & $<3$ & 37 & 49,3 \\
\hline & 03-Jun & 35 & 46,7 \\
\hline & 06-Sep & 3 & 4 \\
\hline & 09-Des & 0 & 0 \\
\hline & $>12$ & 0 & 0 \\
\hline \multirow{5}{*}{$\begin{array}{l}\text { Interval Pengeluaran } \\
\text { Pribadi per bulan } \\
\text { (juta rupiah) }\end{array}$} & $<3$ & 37 & 49,3 \\
\hline & 03-Jun & 35 & 46,7 \\
\hline & 06-Sep & 3 & 4 \\
\hline & 09-Des & 0 & 0 \\
\hline & $>12$ & 0 & 0 \\
\hline \multirow{6}{*}{$\begin{array}{l}\text { Pengeluaran } \\
\text { Keluarga (juta } \\
\text { rupiah) }\end{array}$} & 0 & 66 & 88 \\
\hline & 05-Okt & 6 & 8 \\
\hline & Okt-15 & 2 & 2,7 \\
\hline & $15-20$ & 1 & 1,3 \\
\hline & $20-25$ & 0 & 0 \\
\hline & $>25$ & 0 & 0 \\
\hline \multirow[t]{2}{*}{ Riwayat keluarga } & Tidak ada & 50 & 66,7 \\
\hline & Ada & 25 & 33,3 \\
\hline
\end{tabular}

Uji hipotesis non-parametrik menggunakan korelasi bivariat Spearman pada Tabel 2 menunjukkan korelasi yang signifikan antara derajat PMS dengan usia menarche $(p=0,005)$ dan derajat PMS dengan riwayat keluarga $(\mathrm{p}=0,004)$.

\section{Pembahasan}

PMS dan PMDD memiliki keterkaitan yang erat dengan keadaan kesehatan fisik yang buruk dan adanya tekanan secara psikologis. ${ }^{13}$ Oleh karena itu, hal yang berdampak terhadap peningkatan stres pada seorang perempuan dianggap dapat memiliki pengaruh dalam kecenderungan terjadinya gejala premenstruasi. Paparan stres yang setara juga dapat memberikan dampak yang berbeda karena faktor intraindividual. ${ }^{14}$ Pada penelitian di Jerman, prevalensi PMS tertinggi berada pada kelompok perempuan yang belum menikah, dan kelompok usia 35-44 tahun. ${ }^{13}$ Sedangkan pada penelitian sebelumnya pada populasi perempuan urban di Amerika Serikat, kelompok dengan prevalensi tertinggi ada pada kelompok usia 25-35 tahun. ${ }^{15}$

\section{Korelasi Usia Saat Ini dengan PMS}

Usia saat ini dinilai memiliki hubungan yang berbanding terbalik dengan derajat PMS yang lebih berat. ${ }^{16}$ Faktor usia memiliki peranan terhadap kemampuan pengendalian stres. ${ }^{15}$ Pada umumnya, usia muda dianggap lebih rentan terhadap pajanan stres. ${ }^{15}$ Pada penelitian ini, frekuensi PMS tertinggi ditemukan pada kelompok 26-29 tahun. Pada uji korelasi bivariat antara data usia saat ini pada sampel dan hasil skrining menggunakan PSST belum didapatkan hubungan yang signifikan $(p>0,05)$. Sebuah penelitian di Surabaya juga meninjau korelasi antara usia dan derajat keparahan PMS. ${ }^{17}$ Pada penelitian terhadap subjek dokter perempuan di RSUD Dr. Soetomo yang berusia 20-39 tahun tersebut, didapatkan hubungan yang signifikan dengan nilai $\mathrm{p}=0,018 .{ }^{17}$

Perbedaan ini dapat disebabkan karena rentang usia sampel penelitian yang digunakan pada kedua penelitian berbeda, serta distribusi frekuensi usia sampel yang tidak merata pada masing-masing kelompok usia. Selain itu terdapat faktor perancu di luar variabel usia yang belum dilakukan stratifikasi, seperti jenis pekerjaan/aktivitas subjek yang heterogen. 
Masing-masing pekerjaan memiliki pajanan stres yang relatif berbeda-beda.

\section{Korelasi Status Perkawinan dengan PMS}

Karena distribusi usia sampel relatif muda (dalam kategori remaja akhir sampai dengan dewasa awal), sebagian besar subjek penelitian belum menikah. Pada uji korelasi bivariat antara status perkawinan dengan PMS, belum ditemukan hubungan yang signifikan. Penelitian di RSUD Dr. Soetomo terhadap korelasi variabel status perkawinan dengan derajat keparahan PMS juga mendapat nilai $p$ yang serupa $(p>0,05) .{ }^{17}$ Penemuan dari kedua penelitian tidak mendukung teori yang menyatakan bahwa status perkawinan merupakan faktor protektif pada derajat keparahan PMS. ${ }^{13}$ Hasil yang didapat juga dipengaruhi distribusi yang tidak normal pada variabel status perkawinan dalam sampel yang didapat.

\section{Korelasi Jumlah Anak dengan PMS}

Salah satu kekurangan dari penelitian ini adalah jumlah sampel yang sudah menikah sedikit, sehingga jumlah anak juga dengan sendirinya sedikit. Jumlah anak terbanyak pada sampel adalah sebanyak dua orang anak. Pada penelitian ini, hanya terdapat dua perempuan yang termasuk dalam kategori multipara (telah melahirkan lebih dari satu anak hidup). Data yang didapat belum bisa merepresentasikan hubungan antara variabel jumlah anak dengan derajat keparahan PMS. Penelitian di RSUD Dr. Soetomo menghasilkan $\mathrm{p}=0,079$ pada korelasi antara paritas dan PMS. ${ }^{17}$ Jumlah anak terbanyak pada penelitian tersebut sejumlah tiga orang anak. ${ }^{17}$ Meningkatnya jumlah paritas meningkatkan kecenderungan seorang perempuan untuk mengalami PMS, terutama saat adanya kejadian depresi postpartum. ${ }^{18}$ Hasil dari kedua penelitian tidak mendukung teori mengenai multipara sebagai faktor risiko dari PMS.

\section{Korelasi Usia Menarche dengan PMS}

Prevalensi usia menarche yang didapatkan pada penelitian ini serupa dengan data Kemenkes, yaitu $89 \%$ perempuan mengalami menarche pada usia 12-15 tahun. ${ }^{8}$ Dalam penelitian ini, didapatkan nilai $\mathrm{p}=0,005$ dengan koefisien korelasi sebesar -0,321. Hal ini menandakan bahwa variabel usia menarche memiliki hubungan signifikan yang berbanding terbalik terhadap derajat keparahan PMS. Semakin tua usia menarche, maka kecenderungan keparahan PMS menurun.

Penelitian yang dilakukan pada mahasiswa program studi keperawatan di Lebanon mendapatkan korelasi yang signifikan antara usia menarche dengan terjadinya PMS, nilai $p$ yang didapat $<0,001 .{ }^{19}$ Kedua hasil penelitian mendukung teori yang ada bahwa usia menarche yang terjadi lebih awal memiliki komplikasi pada kesehatan, yaitu salah satunya berupa gangguan pada siklus menstruasi. ${ }^{3}$

\section{Korelasi Pendidikan dengan PMS}

Mayoritas sampel penelitian telah menempuh perguruan tinggi. Dalam hal ini, belum ditemukan korelasi yang signifikan antara pendidikan dengan derajat keparahan gejala PMS. Pada penelitian yang dilakukan di Aceh mengenai hubungan antara karakteristik perempuan dengan derajat keparahan PMS, salah satu variabelnya juga mencakup tingkat pendidikan. ${ }^{20}$ Subjek yang diambil sebanyak 46 bidan, dengan $52,17 \%$ subjek yang telah menempuh pendidikan tinggi. ${ }^{20}$ Penelitian tersebut juga tidak mendapatkan adanya korelasi yang signifikan antara kedua variabel yang ada. ${ }^{20}$ Menurut teori, perbedaan pada tingkat pendidikan dapat menyebabkan seseorang memiliki perspektif yang berbeda dalam menghadapi pajanan stres. $^{20}$ Namun, hasil penelitian pada dua penelitian ini tidak mendukung teori yang menyatakan bahwa perempuan dengan tingkat pendidikan rendah lebih cenderung menderita PMS dibandingkan perempuan dengan tingkat pendidikan yang tinggi. ${ }^{20}$ Hal ini bisa dipengaruhi pemilihan populasi yang relatif berpendidikan tinggi. Seluruh sampel didapatkan sudah mengecap pendidikan dan telah tamat pendidikan dasar/rendah.

\section{Korelasi Pekerjaan dengan PMS}

Menurut teori, faktor pekerjaan secara langsung maupun tidak langsung memiliki hubungan dengan tingkat stres pada perempuan, namun dalam skala yang berbeda untuk masingmasing pekerjaan. ${ }^{20}$ Perempuan yang bekerja di luar rumah dikatakan memiliki kecenderungan untuk menderita PMS lebih tinggi dibanding perempuan yang bekerja di rumah atau sebagai ibu rumah tangga. ${ }^{20}$ Namun, penelitian yang 
sebelumnya tidak mengukur variabel stres sebagai penentu utama kaitan antara pekerjaan dan PMS, sehingga korelasi langsung dengan pekerjaan belum dapat dibuktikan.

Pada penelitian ini, mayoritas subjek bekerja. Namun, bidang yang digeluti berbedabeda. Pada penelitian ini, belum didapatkan korelasi yang signifikan antara pekerjaan dengan PMS. Pada penelitian yang dilakukan di RSUD Dr. Soetomo mengukur variabel stres, variabel pekerjaan tidak diukur karena sudah homogen. ${ }^{17}$ Belum ditemukan signifikansi antara korelasi variabel stres dengan derajat keparahan PMS pada penelitian tersebut. ${ }^{17}$ Untuk menelusuri kemungkinan hubungan ini lebih lanjut, penelitian-penelitian berikutnya perlu memperjelas aktivitas atau pajanan tertentu berdasarkan pekerjaan yang mungkin berkorelasi dengan PMS.

\section{Korelasi Status Sosioekonomi dengan PMS}

Status sosioekonomi yang rendah umumnya berbanding lurus dengan tingkat pendidikan yang rendah. Perempuan dengan status sosioekonomi yang rendah diduga memiliki kecenderungan untuk mengalami PMS lebih dari yang memiliki status sosioekonomi menengah ke atas. Pada penelitian ini, status sosioekonomi digambarkan dalam pendapatan per bulan, pengeluaran pribadi, dan pengeluaran keluarga. Belum ditemukan adanya korelasi yang signifikan antara variabel-variabel tersebut terhadap PMS. Penelitian di RSUD Dr. Soetomo juga dilakukan uji korelasi antara status sosioekonomi dengan PMS. ${ }^{17}$ Hasil dari penelitian tersebut juga tidak menemukan korelasi yang signifikan antara kedua variabel tersebut $(p=0,484) .{ }^{17}$ Kedua penelitian tidak mendukung teori yang ada. Hal ini dapat disebabkan karena sampel memiliki tingkat sosioekonomi yang relatif homogen pada level menengah-tinggi.

\section{Korelasi Riwayat keluarga dengan PMS}

Riwayat keluarga memiliki hubungan erat dengan beragam kejadian patologis maupun kongenital. Salah satunya adalah kejadian PMS. Dalam penelitian ini, ditemukan bahwa riwayat keluarga memiliki korelasi yang signifikan dengan hasil skrining gejala premenstruasi menggunakan kuisioner PSST. Nilai $p$ didapatkan sebesar $0,004 \quad(p<0,05)$ dengan koefisien korelasi sebesar 0,332. Korelasi ini menunjukkan bahwa riwayat keluarga memiliki hubungan sebanding dengan PMS. Penelitian di RSUD Dr. Soetomo juga mendapatkan hasil yang serupa dengan $\mathrm{p}=0,018$ dan nilai $\mathrm{r}=0,256 .{ }^{17}$ Kedua hasil ini mendukung teori mengenai adanya kaitan antara riwayat keluarga dalam terjadinya gejala PMS pada seorang perempuan. ${ }^{16}$

Pada penelitian ini, telah ditelusuri korelasi bivariat antara masing-masing sepuluh variabel bebas (usia saat ini, status perkawinan, jumlah anak, usia menarche, pendidikan, pekerjaan, pendapatan per bulan, pengeluaran pribadi, pengeluaran keluarga, dan riwayat keluarga) dengan hasil skrining gejala premenstruasi menggunakan kuisioner PSST. Ditemukan bahwa terdapat dua variabel bebas (usia menarche dan riwayat keluarga) yang memiliki korelasi signifikan terhadap hasil skrining PSST. Belum ditemukannya korelasi pada variabel bebas lainnya dapat disebabkan karena karakteristik populasi yang distribusinya tidak merata, tidak dilakukannya stratifikasi pada variabel perancu, dan tidak dilakukan analisis hubungan secara multivariat (terutama antara sesama variabel bebas yang berpotensi memiliki keterkaitan dalam mempengaruhi kecenderungan terjadinya PMS). Selain itu, jumlah sampel terbatas dan pada penelitian ini hanya terbatas pada skrining tanpa dilakukan diagnosis pasti.

Penelitian selanjutnya dapat membandingkan faktor-faktor risiko tersebut pada kelompok-kelompok lain, seperti kelompok non-urban dan dengan jumlah sampel yang lebih besar. Persepsi terhadap dan penanganan untuk PMS berbeda pada setiap daerah berdasarkan faktor sosio-kultural yang ada. ${ }^{13}$ Selain itu, dapat dilakukan pengukuran faktor stres dalam sampel, serta faktor-faktor risiko lain yang dapat memengaruhi PMS pada perempuan. Juga perlu ditelusuri bagaimana usia menarche yang dini berkaitan dengan beratnya derajat PMS.

\section{Simpulan}

Pada akhirnya, penelitian ini menunjukkan besarnya masalah PMS pada perempuan, khususnya sampel urban. Perhatian terutama perlu diberikan pada perempuan yang mengalami menarche pada usia dini dan perempuan dengan riwayat keluarga PMS. Oleh karena itu, perlu ada penanganan yang memadai dan kebijakan yang dapat memberikan dukungan 
bagi perempuan yang mengalami PMS, baik di tempat kerja maupun dalam masyarakat.

\section{Daftar Pustaka}

1. Royal College of Obstetricians and Gynaecologist. Management of Premenstrual Syndrome. BJOG: an international journal of obstetrics and gynaecology. 2017;124(3):345-528.

2. Miller K, Rogers S. The estrogendepression connection. Oakland, CA: New Harbinger Publications; 2007;43-4.

3. Pakala C, Gujjula S. Age at menarche and menstrual complications: a cross cultural study among hostel students in Tirupati, Chittoor district, Andhra Pradesh, India. International Journal of Research in Medical Sciences. 2016; 1688-91.

4. Steiner M, Peer M, Palova E, Freeman E, Macdougall M, Soares C. The premenstrual symptoms screening tool revised for adolescents (PSST-A): prevalence of severe PMS and premenstrual dysphoric disorder in adolescents. Archives of Women's Mental Health. 2011;14(1):77-81.

5. Merklinger-Gruchala A, Jasienska G, Kapiszewska M. Effect of air pollution on menstrual cycle length - A prognostic factor of women's reproductive health. Int J Environ Res Public Health. 2017;14:816.

6. Schmelzer K, Ditzen B, Weise C, Andersson G, Hiller W, Kleinstäuber M. Clinical profiles of premenstrual experiences among women having premenstrual syndrome (PMS): Affective changes predominate and relate to social and occupational functioning. Health Care for Women International. 2014;36(10):1104-23.

7. Laksham KB, Selvaraj R, Kar SS. Menstrual disorders and quality of life of women in an urban area of Puducherry: A community-based cross-sectional study. J Family Med Prim Care 2019; 8:137-40

8. Kementerian Kesehatan RI. Health statistics. Profil kesehatan Indonesia tahun 2015. Jakarta: Kementerian Kesehatan RI. 2016.

9. Himpunan Peraturan Tentang Majelis Kehormatan Disiplin Kedokteran Indonesia, peraturan konsil kedokteran Indonesia nomor 15/KKI/PER/VIII/2006 (24 Agustus, 2006)
10. The American college of obstetricians and gynecologists. menstruation in girls and adolescents: using the menstrual cycle as a vital sign. Committee Opinion No. 651. Obstet Gynecol 2015;126:e143-6

11. Sparic R, Mirkovic L, Malvasi A, Tinelli A. Epidemiology of uterine myomas: A review. Int J Fertil Steril. 2016;9(4):42435 .

12. Nevatte T, O'Brien P, Bäckström T, Brown C, Dennerstein L, Endicott J, dkk. ISPMD consensus on the management of premenstrual disorders. Archives of Women's Mental Health. 2013;16(4):27991.

13. Tschudin S, Bertea P, Zemp E. Prevalence and predictors of premenstrual syndrome and premenstrual dysphoric disorder in a population-based sample. Archives of Women's Mental Health. 2010;13(6):48594.

14. Potter J, Bouyer J, Trussell J, Moreau C. Premenstrual syndrome prevalence and fluctuation over time: results from a French population-based survey. Journal of Women's Health. 2009;18(1):31-9.

15. Ramcharan S, Love E, Fick G, Goldfien A. The epidemiology of premenstrual symptoms in a population-based sample of 2650 urban women: attributable risk and risk factors. Journal of Clinical Epidemiology. 1992;45(4):377-92.

16. DeRubeis R and Strunk D. The Oxford handbook of mood disorders. New York: Oxford University Press. 2017:238-49

17. Anggrajani F, Muhdi N. Korelasi faktor risiko dengan derajat keparahan Premenstrual Syndrome pada dokter perempuan [Tesis]. Surabaya: Universitas Airlangga;2011.

18. Ginsburg BE, Carter BF. Premenstrual syndrome: ethical and legal implications in a biomedical perspective. 2012; 298

19. Karout N, Hawai SM, Altuwaijri S. Prevalence and pattern of menstrual disorders among Lebanese nursing students. East Mediterr Health J. 2012;18(4):346-52.

20. Maulana R. Hubungan karakteristik perempuan usia produktif dengan premenstrual syndrome (PMS) di poli obstetri dan ginekologi BPK-RSUD dr. Zainoel Abidin Banda Aceh Tahun 2008 [Tesis]. Banda Aceh: Universitas Syiah Kuala; 2008. 